\title{
Non-market economic value of artificial reefs in Edremit Bay (Eastern Mediterranean, Turkey)
}

\section{Edremit Körfezi'ndeki (Doğu Akdeniz, Türkiye) yapay resiflerin piyasa dışı ekonomik değeri}

\author{
Sezgin Tunca ${ }^{*}$ - Bülent Miran² ${ }^{2}$ Vahdet Ünal $^{3}$ \\ 1 University of Helsinki, Department of Economics and Management, 00014, Helsinki, Finland \\ ${ }^{2}$ Ege University, Department of Agricultural Economics, 35100, Bornova, Izmir, Turkey \\ ${ }^{3}$ Ege University, Department of Fishery and Fish Processing Technology, 35100, Bornova, Izmir, Turkey \\ *Corresponding author: sezgin.tunca@gmail.com
}

Tunca, S., Miran, B. \& Ünal, V. (2016). Non-market economic value of artificial reefs in Edremit Bay (Eastern Mediterranean, Turkey). Ege Journal of Fisheries and Aquatic Sciences, 33(2): 97-107. doi: 10.12714/egejfas.2016.33.2.02

\begin{abstract}
Although the history of artificial reef (AR) deployments in Turkey does not extend far back, there has been a considerable increase in the number of ARs. First aim of this study was to indicate the socioeconomic characteristics of AR stakeholders, commercial fishermen, recreational fishermen and local residents that are affected by ARs in Altinoluk under the Turkish National Artificial Reef Project. The AR relations of the interest groups were measured via reef-related activities, such as commercial fishing, recreational fishing and diving. Mainly, the number of visits to the AR site made by these groups was taken into account. Lastly, the non-market economic value of ARs from the residents was calculated as 3,594,606 via contingent valuation method. Variables affecting willingness-topay and the amounts of individual willingness to pay were also assessed via probit model. The results of the present study have vital importance for decisionmaking process of the AR deployment.
\end{abstract}

Keywords: Artificial reefs, stakeholders, contingent valuation, Altınoluk

Öz: : Türkiye'de yapay resif uygulamalarının tarihi çok uzun olmamakla birlikte, son yıllarda yapay resif uygulamalarında dikkate değer bir artış bulunmaktadır. Bu çalışmanın ilk amacı, Türkiye Ulusal Yapay Resif Projesi'nde Altınoluk'da yapay resiflerden etkilenen ticari balıkçılar, amatör balıkçılar ve yöre sakinleri gibi yapay resif paydaşlarının sosyoekonomik özelliklerini ortaya koymaktır. Bu gurupların yapay resif ile ilişkileri resif ilişkili ticari balıkçlık, rekreasyonel balıkçılık ve dalış gibi aktivitelerle tanımlandı. Temel olarak yapay resif alanına gerçekleştirilen ziyaret sayıları dikkate alındı. Son olarak, yapay resif alanından faydalanmak için yöre sakinleri tarafından yapay resiflere verilen pazar dışı ekonomik değer koşullu değerleme metoduyla yaklaşık 3,594,606 olarak hesaplandı. Bireysel ödeme isteği miktarları ve buna etki eden faktörler probit model ile değerlendirildi. Mevcut çalışmanın sonuçları yapay resif yerleştirmesinin karar verme sürecinde çok büyük öneme sahiptir.

Anahtar kelimeler: Yapay resifler, paydaşlar, koşullu değerleme, Altınoluk

\section{INTRODUCTION}

Scientific studies were initiated to contribute to the sustainability of aquatic species in a variety of ecosystems, such as seas, lakes and freshwaters within an ecological context. Following these studies, artificial reef (AR) deployments were accelerated and became very common during the last three decades (Bortone et al., 2011).

Basically, ARs were previously defined as "one or more natural and human made objects deployed in a marine ecosystem to influence physical, biological and socioeconomic processes related to living marine resources" (Milon et al., 2000). This definition can be broadened because of deployment practices in lakes and in other freshwater ecosystems. Artificial habitats, generally, deployed on the seafloor to conserve sensitive aquatic ecosystems or to increase and contribute to the productivity of resources, have positive effects on commercial and recreational fishing (Seaman and Sprague, 1991).

Local organizations (official and non-official) and local governments supported the use of ARs that were concrete blocks or other scrap materials, such as old navy vessels and aircrafts (Lök et al., 2002) that were also effectively used as ARs by local governmental organizations in the decisionmaking process (Lök and Tokaç, 2000). AR deployments using different shapes, sizes and materials have also been 
successful in the Mediterranean basin, Spain, Portugal and other countries, such as the United States and Japan (GómezBuckley and Haroun, 1994; Bombace et al., 2000; Sempere, 2001; Jensen, 2002; Claudet and Pelletier, 2004; MAGRAMA, 2008).

In addition to fisheries enhancement, ARs create services for SCUBA divers, making ARs very important both economically and socially (Roberts et al., 1985; Milon, 1989; 1988b; Ditton and Baker, 1999; Ditton et al., 2001; Oh et al., 2008; Pendleton, 2004; Sutton and Bushnell, 2007; Whitmarsh et al., 2008). All services provided by ARs are considered as environmental goods and services that cannot be traded in the market and that have a non-market value (Hanemann, 1994; Bateman and Willis, 2002; Haab and McConnell, 2002). Water supply for agricultural production, food supply, the balance and sustainability of natural gases in the air, decreasing risk of epidemics, the sustainability of natural life, recreational fishing, scuba diving, hunting, hiking or trekking in a forest are examples of non-market goods and services (Hanemann, 1994).

AR practices in Turkey have increased in recent years during which limited attention was paid for the biological and technical research (Lök, 1995; Düzbastılar and Tokaç, 2003; Ulaş et al., 2007; Lök and Gül, 2005), and the first economic study considering Turkish waters, was conducted to analyze investment in AR projects (Tiryakioğlu, 2008). In Turkey as the other Mediterranean States, the lack of socioeconomic studies of ARs results in uncertainties of the effects of AR deployments on user groups, such as fishermen, divers, the tourism sector and local people, and prevents the discovery of possible future $\mathrm{AR}$ areas and planning of future projects. Therefore, socioeconomic studies of AR areas covering market and nonmarket values are needed to provide baseline information for scientists and decision makers.

Mainly, we aim to identify socio-demographic and economic characteristics of interest groups including expenditures and attitudes towards ARs and also to calculate the non-market economic value via Contingent Valuation Method in order to provide supportive information for the decision makers.

\section{MATERIAL AND METHOD}

\section{Study site}

Field studies were conducted in the Altınoluk where is a small town driven by tourism and fishery activities; the total population reaches $250,000-300,000$ in summer, with a population of 13,800 in winter (Halil Ataç, personal communication, April 20, 2011) (Figure 1). The region has a wide range of opportunities for recreational and commercial fishing. In particular, boat-based and shore-based recreational fishing activities were an important leisure-time activity for the residents. In addition, the littoral zone of Altınoluk region is composed of sand dunes and affected by cold spring waters, which are carried by streams and brooks from Mount Ida.

The main objectives of the AR deployment are to protect biodiversity, to support small-scale and traditional fisheries, to create new sites for recreational fishing and diving, to protect fish-spawning and nursery areas (e.g., Posidonia meadows) from illegal trawling. The AR deployment was planned as a part of the National Artificial Reef Master Plan.

In the Altınoluk region, approximately 7,000 concrete blocks were proposed for deployment as an AR. Enhancements of habitats, recreational fishing, commercial fishing and diving tourism were the main purposes of the deployment. Commercial fishing activities were identified as crucially important because fishermen's livelihood depends on marine resources. In addition, commercial fishermen are very willing to contribute to such an AR deployment, which is thought to be beneficial for long-term sustainable fisheries management. However, scuba divers and recreational fishermen who fish by boat will be the main beneficiaries of an AR deployment.

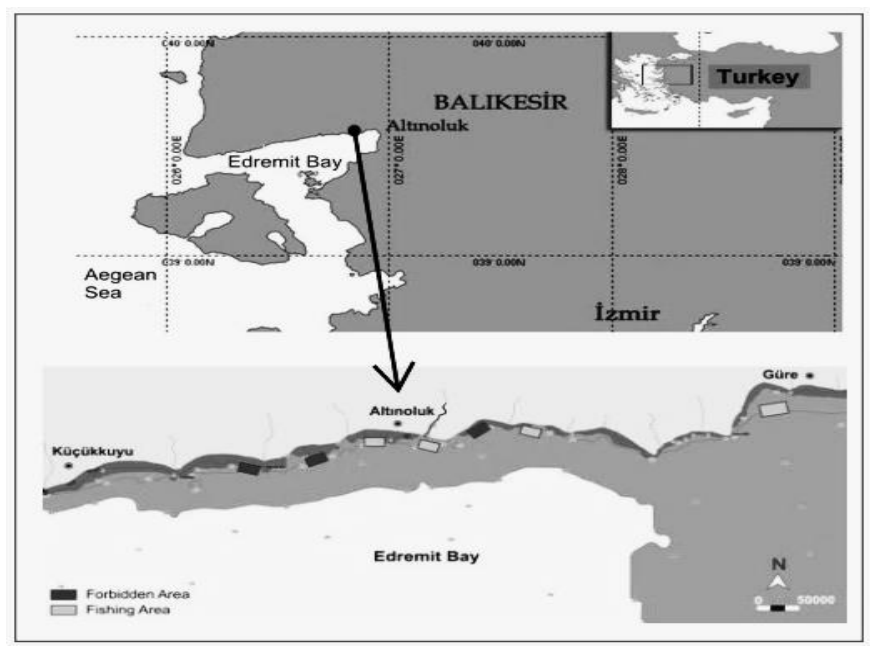

Figure 1. Location of study area on the map. 


\section{Data Collection}

The target survey groups were identified as 20 commercial fishermen who are the members of the Altınoluk Fishery Cooperative, 58 recreational fishermen who participate in recreational fishing onshore or from a boat, 67 households in Altınoluk and the authority of a single scuba-diving organization. A proportional sampling-size formula was used to determine the sampling sizes for each group (Equation 1) (Miran, 2003).

$$
n=\frac{N p(1-p)}{(N-1) \sigma_{p x}^{2}+p(1-p)}(\text { Equation } 1)
$$

Where $\mathrm{n}$ is the sample size, $\mathrm{N}$ is the population of each target group (e.g., commercial fishermen: 55, recreationa fishermen: 400, local residents: 13,800), $p$ is the contribution ratio to $A R s$ ( 0.50 is fitted to reach the maximum sample size), and $\sigma p \times 2$ is the variance (Equation 1).

Face-to-face interviews were conducted to collect data via specific questionnaire forms designed for each group. A representative sample size was calculated for each group according to $95 \%$ confidence intervals and $5 \%$ tolerances.

\section{Data Analysis}

A hypothetical marketplace is created in the contingent valuation (CV) method, which was used successfully to study unchangeable goods in the market (Haab and McConnell, 2002). The CV method has been used for special non-market goods, such as improvements in water quality, days avoiding diseases and fishing days (Haab and McConnell, 2002). In a CV study, the main aim is to create a scenario related to any environmental good or service, and respondents are asked their WTP for an increase in the quantity and quality of the good or service or willingness to accept (WTA) a required amount of money for a certain change (Parkkila et al., 2010). There are some different offer formats for questions used to determine WTP, such as open-ended, dichotomous choice, bidding game or payment cards (Bateman and Willis, 2002; Wedgwood and Sansom, 2003).

Within the CV analysis of the present study, the stated goal was to make a short introduction related to the current situation of ARs, and future improvements were introduced as follows: "Currently, the marine ecosystem in this region is poor of coral reefs. This situation affects both the number of species and biodiversity. The first question within the scenario was as following: "To benefit from the AR site, would you be WTP (1 Euro $=2.5$ Turkish Liras: Exchange Rates, 2011) for future commercial fishing, recreational fishing and scuba diving activities?" Then, the respondents' WTP amounts were elicited through a bidding-game question format (Table 1). Regarding a new AR deployment, improvement and management, the respondents' mean WTP amounts were calculated, and the accepted individual WTP amounts were then attributed to the whole population of the sampling group to estimate the total non-market economic value of ARs. The attribution of the WTP amount was done by multiplying the estimated yearly number of trips with the mean WTP. During the interview, the respondents were asked to accept 10 for one daytrip to ARs, then the bidding game was applied to reach the WTP.

Table 1. Bidding game used in the CV scenario.

\begin{tabular}{|c|c|c|c|}
\hline \multicolumn{4}{|c|}{ Answer to the WTP question (Yes/No) } \\
\hline If Yes, $\boldsymbol{t}_{15}$ & If No, Stop & If No, $\boldsymbol{t}_{8}$ & Yes(Stop) / No \\
\hline If Yes, $\boldsymbol{t}_{20}$ & Yes / No (Stop) & If No, $\boldsymbol{t}_{6}$ & $\begin{array}{c}\text { Yes (Stop) / } \\
\text { No }\end{array}$ \\
\hline If Yes, $\boldsymbol{t}_{25}$ & Yes / No (Stop) & If No, $\boldsymbol{t}_{4}$ & $\begin{array}{c}\text { Yes (Stop) / } \\
\text { No }\end{array}$ \\
\hline If Yes, $\boldsymbol{t}_{30}$ & Yes / No (Stop) & If No, $\boldsymbol{七}_{2}$ & $\begin{array}{c}\text { Yes (Stop) / } \\
\text { No }\end{array}$ \\
\hline
\end{tabular}

*At the time of the readings $€ 1$ equaled $t 2.5$

A probit regression model, of which the parameters are nonlinear, is a discrete-choice model that was used to analyze the relationship between the dependent variable and independent variables. The objective of the model is to create a relational choice probability of the dependent variable $\mathrm{Pi}(0$ 1) with independent variables. In the probit model, a utility index, li, is determined for each observation (Equation 2):

$$
\mathrm{I}_{i}=\beta_{1}+\beta_{2} \mathrm{X}_{i 2}+\ldots+\beta_{k} \mathrm{X}_{i k} \text { (Equation 2) }
$$

The greater li becomes, the greater utility is of $i$ individual from yi $=1$ choice. The general presentation of the probit model is shown below (Equation 3):

$$
P_{i}=F\left(I_{i}\right)=F\left(\beta_{1}+\beta_{2} \mathrm{X}_{i 2}+\ldots+\beta_{k} \mathrm{X}_{i k}\right)=F\left(X_{i}^{\prime} \beta\right)
$$

(Equation 3)

In the formula above, $\mathrm{F}(\mathrm{li})$ is an added probability function based on standard normal $(0,1)$ random variables. The estimators in the probit model are obtained by the maximum likelihood (ML) method (Gujarati, 2004).

Probit models were used to estimate the mean willingness to pay (MWTP) of the respondents. While the dependent variable of the probit model is a dummy variable ( 1 or 0$)$ for approvals of a bidding-game question, independent variables were composed of offered prices and socio-economic variables. MWTP amounts were calculated using the formula below (Equation 4; 5):

$$
\begin{gathered}
\text { MWTP }=\frac{\vartheta}{\hat{\beta}} \text { (Equation 4) } \\
\hat{\vartheta}=\overline{\mathrm{X}} \hat{\beta} \text { (Equation 5) }
\end{gathered}
$$

Where $\hat{\beta}_{\text {Offered price }}$ is a parameter of the offered price in the probit model of a CV scenario, $\bar{X}$ is the mean value of variables and $\hat{\vartheta}$ is the index value determined based on the 
mean values of other variables in the model in which an offered price is not included.

\section{RESULTS}

\section{Demographics}

Results derived from questionnaires indicate that a total of $55.0 \%$ of the commercial fishermen were in the $26-45$ year age group, while $40.0 \%$ of them were in the $46-60$ year age group. Among the recreational fishers interviewed, the 26-45 year age group composed the highest portion and secondly the 46-60 year age group, as in the case of the commercial fishers. Furthermore, 6 recreational fishermen older than 61 years and 1 recreational fisherman younger than 26 years were interviewed. Among the household respondents who participated in the research, the 26-45 year and 46-60 year age groups had $53.7 \%$ and $31.3 \%$ of the respondents, respectively, whereas respondents older than 61 years and younger than 26 years constituted minorities. A total of $65.0 \%$ of the commercial fishers, $79.3 \%$ of the recreational fishers, $59.7 \%$ of the local people and generally $68.3 \%$ of all of the respondents were married. The most common education levels of commercial fishermen were about eight years of secondary education. In contrast, recreational fishermen have higher educational levels, with an average of 9.3 years. The mean number of years of education for the local people, 10.8, is slightly higher than the general average for all of the respondents' education levels (9.9 years).

The recreational fishermen had the highest proportion of members with social security (89.7\%). Following them, $80.6 \%$ of the local people and $60.0 \%$ of the commercial fishermen had social security. The primary occupation of the commercial fishermen was commercial fishing $(85.0 \%)$, whereas 3 commercial fishermen performed this activity as a second job after retirement. A total of $34.5 \%$ of the recreational fishermen were retired individuals. Following the retired individuals, public servants and freely occupied individuals constituted the majority of this group. For local people and recreational fishermen, retired people composed the largest portion among the interviewed individuals. Among all of the respondents, retired persons composed the majority, with 40 individuals, while freely occupied persons, public servants, workers for a national company and fishermen almost homogeneously composed the majority of the rest of the individuals (105).

Service, management, commercial fishing and free occupations special to the region were the dominant second occupations of the recreational fishermen interviewed; however, for the local people, construction, transportation, technology and service sectors were determined as the most common second occupations.

The average monthly income of the commercial fishermen was $1,192.5$, while $75 \%$ of them were in the $501-1,500$ income interval and $25 \%$ of them were in the $1,501-3,000$ income interval. Of the recreational fishing participants, $79 \%$ were in the 501-1,500income interval, although the mean monthly income was determined to be 1,354.1 greater than the commercial fishers' monthly mean income. In contrast, the local people's monthly income was mostly in the 1,501-3,000 income interval, with a mean income of $1,360.5$. Moreover, for the local people, $30 \%$ had an income of $3,001-5,000$, and $15 \%$ were in the 5,001-10,000 income interval. Overall, the 1,501-3,000 TL $(66 \%)$ and 3,001-5,000 TL (24\%) income intervals composed the majority.

The mean number of individuals that commercial fishermen were responsible for was nearly 2 and that of the average household population was 3 . These numbers were different for recreational fishermen, who were on average responsible for 1 individual, and the total family population was 3 , as in the case of commercial fishermen.

The local people were on average responsible for 2 individuals, and the mean household number was 3. Generally, the mean number of individuals that all of the respondents were responsible for was nearly 2 , and the mean household population was nearly 3. A total of $80 \%$ of the members of Altınoluk Fishery Cooperative stated that the fishery cooperative was successful, whereas the rest indicated that the fishery cooperative was unsuccessful. Moreover, none of the commercial fishermen who were interviewed were members of a non-governmental organization (NGO). However, $91 \%$ of the recreational fishermen had no membership in any NGO. Of the $9 \%$ who were NGO members, the respondents primarily took part in fishery cooperatives, spear fishers' associations, sport shooting associations and sport fishing associations outside of the region. A total of $73 \%$ of the local people assessed had no membership in any NGO, while $27 \%$ indicated their membership of local NGOs, city political party organizations or recreational fishing, hunting and shooting organizations outside of the region. In total, $60 \%$ of all of the respondents indicated their ownership of the house in which they reside. The ownership ratios among the groups were $75 \%$ for the commercial fishermen, $60.3 \%$ for the recreational fishermen and $55.2 \%$ for the local people.

\section{General AR Knowledge and Sources}

Among all of the groups, $80 \%$ of the commercial fishermen, $79.3 \%$ of the recreational fishermen, $46.3 \%$ of the local people and generally $64.1 \%$ of all of the respondents said "Yes" in response to the question, "Have you ever heard of the AR concept?" Among the respondents who said, "Yes", for the commercial fishermen, a fishery cooperative was determined to be the main source of information, and for the recreational fishermen, the results showed that close social surroundings become the first source of information prior to the fishery cooperative. For the local people, the information source varied, but again, close social surroundings were the most stated choice. Among the research groups, $55 \%$ of the commercial fishermen, $52 \%$ of the recreational fishermen, $9 \%$ of the local people and $68 \%$ of all of the interviewed 
respondents indicated the following: "I am aware of the AR deployments in Altınoluk within the National Artificial Reef Project".

\section{Activities of Possible User Groups}

For a possible AR deployment in the proposed AR zone, $95 \%$ of the commercial fishermen are current and potential commercial users who confirmed that they conduct commercial fishing activities in the zones. The technical and economic dimensions of commercial fishermen are also taken into account to identify the commercial pressure on the zone in question. In terms of general commercial fishing days, $40 \%$ of the commercial fishermen fish nearly 50 days in a year, and $35 \%$ fish 101-200 days in a year. For the AR deployment zone, $50 \%$ of the commercial fishermen stated that there are 101-200 days and $50 \%$ stated that there are 201-365 days for yearly fishing periods, which shows a great relationship between the AR site and commercial fishermen. The mean number of commercial fishing days was 235 , while that number showed a disparity of 115 days in the AR site for commercial fishing. However, the commercial fishermen stated that there are 31\% more commercial fishing days if the AR was established. In addition, $80 \%$ of the commercial fishermen indicated that they use the AR site for other purposes, such as recreational fishing and recreational trips. Among these activities, recreational sea trips were the most important.

In contrast, $69 \%$ of the recreational fishermen stated that they use the AR site for recreational fishing by boat. The average number of days of AR site use by the recreational fishermen was 34 days, whereas this number showed an extreme upward trend with a $158 \%$ increase to 89 days if the AR were deployed. The yearly total number of recreational fishing days was 124 days. Furthermore, $69 \%$ of the recreational fishermen use the AR site for recreational trip and recreational diving activities, $44.4 \%$ of them use the site for recreational trip, $27.8 \%$ use the site for recreational diving, and finally, $27.8 \%$ use the AR site for both recreational trip and recreational diving purposes.

Of the local residents, $52 \%$ of them use the AR site for recreational fishing, recreational trips and diving purposes, $63 \%$ use the site only for recreational trips, $14 \%$ use the site only for recreational fishing, $9 \%$ use the site only for recreational diving and $11 \%$ use the site for both recreational fishing and recreational diving purposes. Generally, the local residents stated that there are nearly 44 days for all of these activities in a year. After an AR deployment, $75 \%$ of the local residents indicated willingness to attend activities after reef deployment, a significant increase from $52 \%$. After an AR deployment, the local residents indicated that they would spend 18.5 days for recreational fishing and 5.2 days for recreational diving.

Finally, one diving club in the Altınoluk region, which is open only in summer, was assessed. In the 2009 summer season, nearly 300 dives were conducted by the club. Generally, the diving club is composed of people who come from outside of the region and abroad, so neither the number of total divers was not determined, nor were interviews conducted. The head of the diving club remarked that the main beneficiaries of an AR deployment are diving clubs and emphasized the importance of future possible use of ARs for recreational dives.

\section{Technical and Economic Characteristics of Commercial Fishing}

The fishing-related expenses of commercial fishermen were identified. Fuel expenses composed the largest share of the expenses, with an average daily cost of 28.9 , while bait, food and other costs were on average 10.5, 15 and 10.8, respectively. The mean daily catch of commercial fishermen was $11.4 \mathrm{~kg}$. Long-line, set nets or both were the main fishing gears used by the commercial fishermen. Among these gears, set nets composed the highest share $(60 \%)$, while both set nets and long-lines were used by $25 \%$ of the commercial fishermen. Regarding the length of set nets, the commercial fishermen who used gillnets and trammel nets generally fish with nets shorter than 2,000 meters. Generally, the mean set-net length was 2,820 meters, whereas that value was only 1,910 meters for gillnets and only 1,740 meters for trammel nets. Furthermore, 8 commercial fishermen only fish with thick longline, 4 commercial fishermen only use thin long-line, and 4 commercial fishermen use both of these long-line types. The average length, age and engine power of the commercial fishing vessels was $7.4 \pm 1.4 \mathrm{~m}, 15 \pm 7.8$ years and $41 \pm 37.7$ horse power, respectively.

Technical and Economic Characteristics of Recreational Fishing

The proportion of only on-shore recreational fishing was $48 \%$, only on-boat recreational fishing composed $29 \%$, and both on-boat and on-shore recreational fishing composed $14 \%$ of the recreational fishing effort. Of the recreational fishermen, $86 \%$ fish with fishing rod and line, whereas $7 \%$ fish with a fishing spear. For a one-day recreational fishing trip for recreational fishermen, on average, 18.1 for transportation, 8.6 for bait, 6 for gear and 7.2 for other costs were the main costs. The total yearly expenditures of recreational fishermen, on average, included 605.4 for fishing gear, 335.9 for bait and 561.7 for transportation.

A total of $74 \%$ of the recreational fishermen stated that they used small boats or vessels that have on average 5.7 meters of length and 10.7 HP engine power for recreational fishing. A total of $41.9 \%$ of the shore-based recreational fishermen go fishing with their own vessel, while the rest use a friend's vessel. The fishers who own a vessel have on average 600 of yearly repair and maintenance costs and 629.2 of yearly fuel costs. The mean depth and distance from shore for recreational fishing was 32 meters and 2,149 m, respectively.

\section{WTP amounts}

Within a CV scenario, the WTP amounts of the respondents were determined for each group using a bidding-game format. Generally, $75 \%$ of the commercial fishermen, $91 \%$ of the 
recreational fishermen and $85 \%$ of the local people were willing to pay for a trip to an AR. The MWTP amounts were 18.4, 17.8 and 13.4 for the commercial fishermen, recreational fishermen and local people, respectively (Table 2).

Table 2. Descriptive statistics of WTP amounts

\begin{tabular}{|c|c|c|c|c|}
\hline & 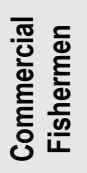 & 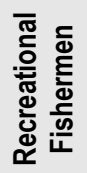 & 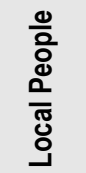 & 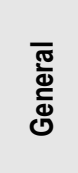 \\
\hline Mean & 18.40 & 17.88 & 13.36 & 15.86 \\
\hline Minimum & 0 & 0 & 0 & 0 \\
\hline Maximum & 100 & 100 & 50 & 100 \\
\hline $\begin{array}{l}\text { Standard } \\
\text { Deviation }\end{array}$ & 24.49 & 16.38 & 10.31 & 15.47 \\
\hline $\mathrm{n}$ & 20 & 58 & 67 & 145 \\
\hline
\end{tabular}

*At the time of the readings $€ 1$ equaled $\aleph_{2.5}$

In terms of other individual characteristics, the commercial fishermen between 46 and 60 years of age had significantly higher WTP amounts than the younger individuals. In contrast, a decreasing trend linear with age was observed for the stated WTP amounts of the recreational fishermen. The local residents included in different age groups reported MWTP amounts quite close to the general MWTP amount.

The married individuals in the three groups reported significantly higher WTP amounts than single or widowed individuals. Individuals with different education levels did not show any disparity in their stated WTP amounts. Moreover, commercial fishermen who graduated from primary school reported higher WTP amounts than the commercial fishermen with more education. In contrast, the recreational fishermen who had graduated at least from high school reported significantly lower WTP amounts. The existence of social security among the individuals did not show any considerable effect on the stated WTP amounts. Interestingly, commercial and recreational fishermen who had a second job reported substantially and significantly lower WTP amounts than ones who did not have a second job.

The WTP amounts and respondents' monthly incomes were compared. The commercial fishermen with a monthly income under 1,000 reported higher WTP amounts than those with higher monthly incomes. For the recreational fishermen and local people, individuals included in the 3,000-5,000 income interval reported higher WTP amounts than ones who had lower monthly incomes, as expected. The commercial fishermen and local people who were responsible for more than 2 individuals had greater WTP than ones who were responsible for fewer than 2 individuals, and the converse situation was found for the recreational fishermen. The commercial fishermen who had a total family population over 3 individuals reported higher WTP amounts than the ones who had a family population less than 3 , and again, this pattern was opposite for the recreational fishermen and local people. The commercial fishermen and local people who owned a house reported higher WTP amounts than ones who did not own a house. However, the opposite situation was valid for the recreational fishermen. Similarly, the commercial fishermen and local people who had heard of the AR concept beforehand reported higher WTP amounts than recreational fishermen. Moreover, the commercial fishermen and recreational fishermen who were aware of the AR project reported higher WTP amounts than ones who were not aware of the project.

\section{Econometric Model}

Within the CV scenario, the WTP amounts of the respondents and some demographic variables were used to calculate MWTP amounts via a probit model. Only the local people's WTP was considered for the non-market economic value of ARs. Definitions of the variables used in the probit model are shown in Table 3.

Table 3. Dependent, independent variables and their definitions

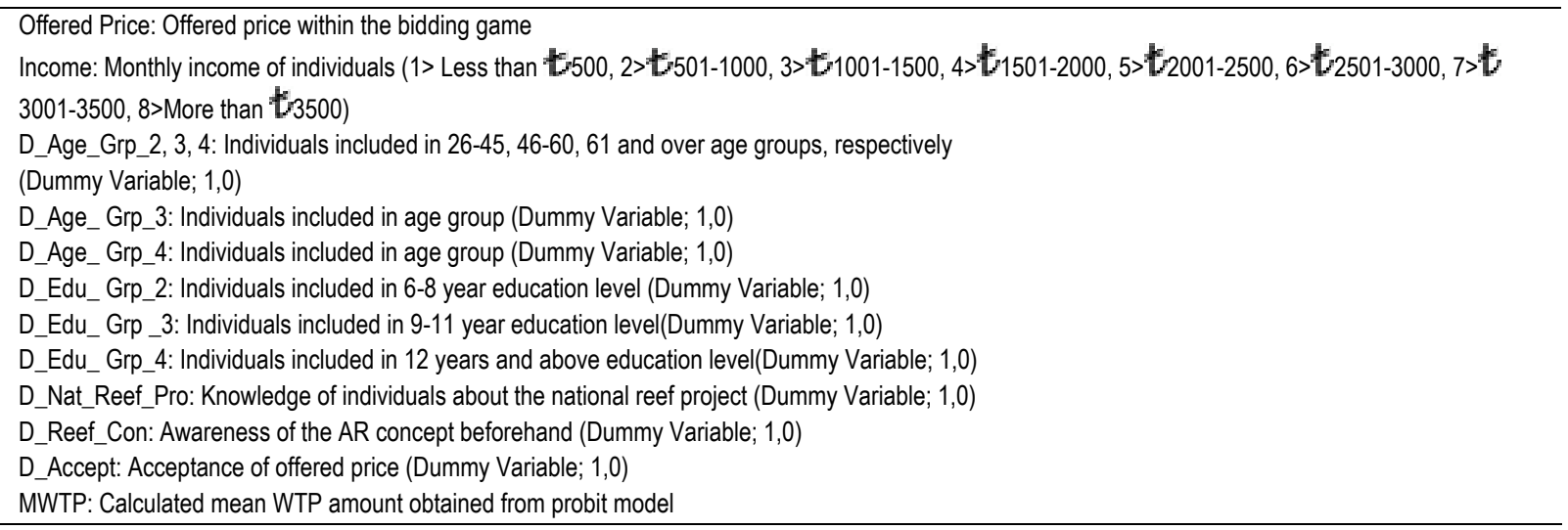


According to the probit model, a positive effect of income on the stated WTP amounts was observed. In contrast, the WTP amounts showed a decreasing trend as the age of individuals increased. The respondents who had 8 years of secondary education reported higher WTP amounts than the ones who had over 8 years of education. The local people who were aware of the AR project in the region reported lower WTP amounts than those who were not aware of the AR project. A positive relationship between WTP amounts and knowledge about the AR concept was found (Table 4).

Table 4. Estimation of probit model

\begin{tabular}{|c|c|c|c|c|c|}
\hline $\begin{array}{l}\text { Explanatory } \\
\text { Variables }\end{array}$ & Coefficient & $\begin{array}{l}\text { Standard } \\
\text { Error }\end{array}$ & $\begin{array}{c}\mathrm{b} / \\
\text { Standard Error }\end{array}$ & $P[|Z|>Z]$ & Mean X \\
\hline Constant & 2.21 & 0.34 & 6.44 & 0.00 & \\
\hline Offered_Price & -0.11 & 0.01 & -14.06 & $0.00^{*}$ & 13.36 \\
\hline Income & 0.00 & 0.00 & 6.65 & $0.00^{*}$ & 1382.69 \\
\hline D_Age_Grp_2 & -2.10 & 0.29 & -7.24 & $0.00^{*}$ & 0.55 \\
\hline D_Age_Grp_3 & -2.32 & 0.33 & -7.01 & $0.00^{*}$ & 0.32 \\
\hline D_Age_Grp_4 & -3.54 & 0.55 & -6.38 & $0.00^{*}$ & 0.03 \\
\hline D_Edu_Grp_2 & 0.34 & 0.24 & 1.38 & 0.17 & 0.27 \\
\hline D_Edu_Grp_3 & -1.66 & 0.30 & -5.47 & $0.00^{*}$ & 0.33 \\
\hline D_Edu_Grp_4 & -1.54 & 0.32 & -4.78 & $0.00^{*}$ & 0.30 \\
\hline D_Nat_Reef_Pro & -1.52 & 0.24 & -6.29 & $0.00^{*}$ & 0.09 \\
\hline D_Reef_Con & 0.34 & 0.16 & 12.04 & $0.04^{*}$ & 0.47 \\
\hline & $\begin{array}{r}\text { Dependent variable } \\
\text { Number of Observations } \\
\text { Logarithmic Likelihood Function } \\
\text { Number of Parameters } \\
\text { Constricted Logarithmic Likelihood } \\
\text { McFadden Pseudo R-Square } \\
\text { Chi squared } \\
\text { Freedom degree } \\
\text { Likelihood [Chi squared >p value] } \\
\text { Hosmer-Lemeshow Chi squared } \\
\text { P value (degree of freedom: } 7) \\
\text { WTP ( }(\text { t) } \\
* \\
\text { Dependent variable }\end{array}$ & $\begin{array}{l}\text { D_Accept } \\
660 \\
-273.60 \\
11 \\
-442.94 \\
0.38 \\
338.69 \\
10 \\
0 \\
11.82 \\
0.11 \\
17.04 \\
\text { Statistically } \\
\text { D_Accept }\end{array}$ & ificant at $\alpha=0.05$ & & \\
\hline
\end{tabular}

*At the time of the readings $€ 1$ equaled ${ }_{2.5}$

The MWTP of the local people for a daily visit to the ARs was calculated using the probit model. In the case of an AR deployment, 7 local individuals (10.1\%) reported having an unwillingness to visit the ARs sites, whereas 60 individuals (89.6\%) reported being willingness to visit 17.1 times in a year.

The total population of Altınoluk was estimated at 13,800 individuals, which was the attributed size of the local people's sample size. A total of $89.6 \%$ of the local people, i.e., 12,358 individuals in Altınoluk, are estimated to conduct recreational fishing, diving or trip activities if an AR is deployed.

The MWTP of the local residents was calculated as follows according to the probit model (Equation $4 ; 5)$ :

$$
\begin{gathered}
\text { MWTP }=\frac{\vartheta}{\beta_{\text {Offered Price }}}(\text { Equation 4) } \\
\hat{\vartheta}=\bar{X} \hat{\beta} \quad \text { (Equation 5) }
\end{gathered}
$$

where $\hat{\beta}_{\text {Offered price }}$ is a parameter of the offered price in the probit model within the CV scenario, $\bar{X}$ is mean value of dependent variable and $\hat{\vartheta}$ is the index value of the means of other variables in the model that did not include an offered price within the CV scenario. According to the probit model, the WTP value was $t$ 17.04. 
Within the calculation below, first, the total number of projected visits (TNV) was calculated on the basis of the average yearly number of visits (NV) and number of individuals (NI) who were willing to visit ARs (Equation 6): TNV $=\mathrm{NV} \times \mathrm{NI}$ $=17.1 \times 12,358=210,951$. Then, the estimated economic value (EEV) of the ARs was calculated by multiplying the TNV and MWTP amount obtained using the probit model (Equation 7): $E E V=T N V \times M W T P=210,951 \times 17.04=3,594,606$ that is the estimated economic value (EEV) of the ARs due to the recreational use by local residents.

\section{Management Aspects}

Results regarding the management of ARs showed that $80 \%$ of the commercial fishermen, $50 \%$ of the recreational fishermen, $67 \%$ of the local residents and generally, $62 \%$ of all of the respondents agreed on the allocation of the AR site for different purposes. A few official and unofficial foundations were voted upon, with different results for each group. A fishery cooperative, a reef-guard station of a related ministry and the coast guard were highly voted options for reef management. Most of the commercial fishermen interviewed had a tendency to vote to give the management process to a fishery cooperative. For the recreational fishermen, this opinion varied among the different options of a reef-guard station (31\% of the votes), fishery cooperative (27.6\%) and coast guard (10.4\%). In contrast, $30 \%$ of the local residents voted for a reef-guard station, $16.4 \%$ voted for the cooperative and a reef-guard station, and the rest of the local residents indicated that the management of ARs should be in the hands of different foundations. The general picture of AR management showed that fishery cooperatives and a reef-guard station received the greatest number of votes for reef management, with $27.6 \%$ of the shares, while the rest of the votes varied among the municipality, the coast guard, diving clubs and local residents.

\section{DISCUSSION AND CONCLUSION}

This study mainly represents information on sociodemographic and economic dimensions of AR user and nonuser groups. Socio-demographic profile and economic profile and AR use types of each survey group showed differences among themselves. Additionally, the study provided information on willingness to pay of residents with an estimation of nonmarket economic value of ARs in the Edremit Bay.

First, the respondents agreed that ARs are biologically useful materials have also good knowledge levels regarding the biological effects of ARs in similar with the results from study conducted by Ramos et al. (2007) and, current ARs can contribute to the number of user groups and increase their activities, including diving, boat-based recreational fishing and other AR related recreational activities, by increasing the number of recreational days which supports the hypothesis that ARs create demand in local economy (Hanni and Mathews, 1977; Bell et al., 1998; Hiett and Milon, 2002). Additionally, the presence of ARs triggered significant increases in the number of future commercial and recreational trips compared to past annual number of trips. These increases in the number of future trips of all survey groups will likely to generate positive impact in local and national economy.

Regarding the future management aspects of ARs, the commercial fishermen stated that they preferred to give the control and management of future ARs to a fishery cooperative; however, the recreational fishermen and residents preferred to the decision-making process to a reef guard and control station, which is under the control of a local ministry. In contrast, almost all respondents agreed on the distribution of the use rights of a potential AR area among different use purposes, including commercial fishing and recreational fishing that would be a result to benefit for cooperative management of ARs.

Further, to identify the potential non-market economic value of ARs, a CV method was conducted in an experimental scenario. WTP amounts for daily fishing trips to the AR location under a CV scenario were examined. The mean WTP of the commercial fishermen ( $18.4=€ 7.4$ ) was greater than that of the other groups possibly because of the CF's dependence to the marine resources as a livelihood, however; this value was slightly lower for non-commercial users, $\operatorname{RF}(17.9=€ 7.2)$ and $\operatorname{LR}(13.4=€ 5.4)$.

The residents' mean WTP amount was calculated using the probit model as 17.04. By attributing the economic value to the total population, the non-market economic value from the residents was calculated as $3,594,606$, indicating the high economic value of ARs. This value is similar to the WTP amounts generated from studies conducted in the United States. For instance, in Dade County, Florida, Milon (1988a) assessed the WTP amounts of related user groups for a new AR location. Within this study, positive advantages of ARs were put forward, and a $\$ 707,000$ yearly contribution of ARs was estimated; a large part of this value was related to non-users. Johns et al. (2001) determined the use value of artificial and natural reefs in southwest Florida and for a new AR deployment calculated a value of $\$ 4,000,000$, close to the value found in this study. From another perspective, Johns (2004) showed $\$ 7,200,000$ yearly expenditures resulting from reef use. By considering the countrys' economic development levels, the values from different previous studies and current study have not showed great difference among themselves (Table 5; Table $6)$.

This study has also confirmed the effectiveness of CV method in pre-development assessment of ARs especially as the possible user groups had good understanding and also considerable knowledge on dimensions of ARs and, further, the non-user benefits can be measured via CV method since they cannot be measured with the travel cost method (Milon, 1989). 
Table 5. Some Market Value Estimates for ARs (adopted from Pendleton, 2004)

\begin{tabular}{|c|c|c|c|}
\hline Author & Location & Habitat Type & $\begin{array}{l}\text { Market Value Per Person-Day } \\
\text { (\$2004, figures are rounded) }\end{array}$ \\
\hline Hiett and Milon (2002) & Gulf of Mexico & Oil and Gas Structures & $\$ 119$ \\
\hline McGinnis et al.(2001) & Southern California & Platform Grace (Oil Rig) & $\$ 64$ \\
\hline Ditton and Baker (1999) & Texas & Various types of ARs & $\begin{array}{l}\text { \$185 for resident } \\
\$ 194 \text { for non-residents }\end{array}$ \\
\hline $\begin{array}{l}\text { Ditton et al.(2001), } \\
\text { Bell et al.(1998) }\end{array}$ & North West Florida & $\begin{array}{l}\text { Ships, reef balls, and other private and } \\
\text { public ARs }\end{array}$ & $\begin{array}{l}\$ 50 \text { for residents } \\
\$ 90 \text { for visitors }\end{array}$ \\
\hline Johns et al.(2003) & South East Florida & $\begin{array}{l}\text { Ships, reef balls, and other private and } \\
\text { public ARs }\end{array}$ & $\begin{array}{l}\$ 61 \text { for residents } \\
\$ 204 \text { for visitors }\end{array}$ \\
\hline Wilhelmsson et al.(1998) & Eilat, Israel & Navy Ship & $\$ 28$ \\
\hline Brock (1994) & Waikiki & Surplus yard oiler & $\$ 26-\$ 60$ \\
\hline
\end{tabular}

Table 6. Some Non-Market Value Estimates for ARs (adopted from Pendleton, 2004)

\begin{tabular}{|c|c|c|c|c|}
\hline Author & Method & Location & Habitat Type & $\begin{array}{l}\text { Market Value Per } \\
\text { Person-Day }(\$ 2004)\end{array}$ \\
\hline \multicolumn{5}{|l|}{ DIVING ON ARs } \\
\hline $\begin{array}{l}\text { Ditton and Baker (1999) } \\
\text { Ditton et al.(2001) }\end{array}$ & $\begin{array}{l}\text { CVM (1.dichoto- } \\
\text { mous choice, } \\
\text { 2. open-ended) }\end{array}$ & Texas & Various types of ARs & $\begin{array}{l}\text { 1. } \$ 75 \\
\text { 2. } \$ 45\end{array}$ \\
\hline Bell et al.(1998) & Travel Cost & North West Florida & $\begin{array}{l}\text { Ships, reef balls, and other } \\
\text { structures }\end{array}$ & $\$ 11$ \\
\hline Roberts et al.(1985) & CVM & Gulf of Mexico & Petroleum Structures & $\begin{array}{l}\text { \$339 annually per diver } \\
\text { Residents: }\end{array}$ \\
\hline Johns et al.(2003) & $\begin{array}{l}\text { CVM } \\
\text { (dichotomous choice) }\end{array}$ & Southeast Florida & $\begin{array}{l}\text { Ships, reef balls, and other } \\
\text { private and public ARs }\end{array}$ & $\begin{array}{l}\$ 5.45 \text { (new artificial reefs) } \\
\$ 15.73 \text { (to maintain } \\
\text { existing artificial reefs) }\end{array}$ \\
\hline \multicolumn{5}{|c|}{ DIVING AND FISHING ON ARS } \\
\hline Milon (1988a) & CVM & Florida & $\begin{array}{l}\text { Network of } 7 \\
\text { different reefs }\end{array}$ & $\$ 29.04$ to $\$ 42.77$ per year \\
\hline Milon (1989) & CVM & Florida & $\begin{array}{l}\text { Ships and steel } \\
\text { debris }\end{array}$ & $\$ 4.48$ to 127.56 per year \\
\hline
\end{tabular}

This study has also confirmed the effectiveness of CV method in pre-development assessment of ARs especially as the possible user groups had good understanding and also considerable knowledge on dimensions of ARs and, further, the non-user benefits can be measured via CV method since they cannot be measured with the travel cost method (Milon, 1989).

The residents who have knowledge on the current national reef project in the region were less like for willing to pay to benefit from AR site whereas, the residents who have previous knowledge on AR concept were willing to pay much higher than the ones who do not have knowledge. These results also can be related to the findings in previous studies by Milon that showed the respondents who have never utilized ARs had positive values by taking into account their option (for future benefits by their own use) or their existence (preserving for the future) values (Milon, 1989). Low AR relevance cannot be perceived as low or no willingness to pay. With the econometric models used, different interactions among the studied variables were determined. A positive effect of income on the stated WTP amounts was identified. By analyzing WTP amounts according to the different age groups, a negative relationship was found between the WTP amount and age variables. In addition, the probit model also showed significantly higher values for respondents who had only 8 years of education. The respondents who had knowledge of the National Reef Project reported lower WTP than the rest, but this finding conflicted with the positive correlation of WTP with knowledge of the AR concept. In the light of these considerations, LR who are aware of the certainty for the AR deployment do not have much WTP.

This study also demonstrates the potential of commercial fishing, recreational fishing, recreational trip and recreational diving activities on the AR zone in question. Generally, the individuals who accepted to pay any monetary value stated that they would gain benefits from an AR deployment. Sensitivity to nature and interests in reef projects were identified as other reasons for acceptance of a required payment. The existence of a considerable number of individuals who are willing to pay demonstrates the great economic value of ARs. 
Consequently, in this study, the non-market benefits of user and non-user groups of ARs who were estimated to relate to a proposed $A R$ in the region were calculated. By considering commercial fishermen, recreational fishermen, local residents and a diving club to determine the technical, economic and social activities of users and non-users, this study was designed to identify the relationship of an AR with the local economic activity. The effect of high commercial and recreational use pressure on the market and non-market economic benefits in especially some certain AR sites should be determined in future studies. As an overall conclusion we can say that in Turkey, with a few number of biological and socioeconomic studies, it is difficult to understand potential AR user groups and their relevance to ARs. Based on this first study of the social and economic benefits of ARs, an efficient planning, monitoring and management process can be

\section{REFERENCES}

Bateman, I. \& Willis, K.G. (2002). Valuing Environmental Preferences: Theory and Practice of Contingent Valuation Method in the US, EU and Developing Countries. Oxford University Press, USA, $692 \mathrm{pp}$.

Bell, F., Bonn, M. \& Leeworthy, V. (1998). Economic Impact and Importance of Artificial Reefs in Northwest Florida. NOAA Paper Contract Number MR235.

Bombace, G., Fabi, G. \& Fiorentini, L. (2000). Artificial reefs in the Adriatic Sea. In Jensen, A.C., Collins, K.J. and Lockwood, A.P.M. (Eds.) Artificial Reefs in European Seas. Kluwer Academic Publications, Dordrecht, The Netherlands, 31-63.

Bortone, S. A., Brandini, P. P., Fabi, S. \& Otake, S. (2011). Artificial reefs in fishery management. Florida: CRC Press, $350 \mathrm{p}$.

Brock, R. (1994). Beyond Fisheries Enhancement: Artificial Reefs and Ecotourism. Bulletin of Marine Sciences, 55(2-3): 1181-1188

Claudet, J. \& Pelletier, D. (2004). Marine protected areas and artificial reefs: A review of the interactions between management and scientific studies. Aquatic Living Resources, 17 (02), 129-138. doi: 10.1051/alr:2004017

Ditton, R.B. \& T.L. Baker (1999). Demographics, Attitudes, Management Preferences, and Economic Impacts of Sport Divers using Artificial Reefs in Offshore Texas Waters. Report prepared for the Texas Parks and Wildlife Department through a research contract with Texas A\&M University. $44 \mathrm{pp}$.

Ditton, R. B., Thailing, C.E. Riechers, R. \& Osburn, H. (2001). The Economic impacts of sport divers using Artificial Reefs in Texas Offshore Waters. Proceedings of the Annual Gulf and Caribbean Fisheries Institute, 54: 349360.

Düzbastılar, F.O. \& Tokaç, A. (2003). Determination of effects of artificial reef size on local scouring phenomena resulting from wave action Ege Journal of Fisheries and Aquatic Science,20 (3-4): 373 - 381.

Gómez-Buckley, M. C. \& Haroun, R.J. (1994). Artificial reefs in the Spanish coastal zone. Bulletin of Marine Science, 55(2-3), 1021-1028.

Gujarati, N.D. (2004). Basic Econometrics. McGraw-Hill, 4th Edition, USA. $1002 \mathrm{pp}$.

Haab, T.C. \& McConnell, K.E. (2002). Valuing Environmental and Natural Resources, Econometrics of Non-Market Valuation. Edward Elgar Publishing Limited. 352 pp. doi: 10.4337/9781843765431

Hanemann, W. M. (1994). Valuing the Environment Through Contingent Valuation. Journal of Economic Perspectives, 8: 19-43.

Hanni, E. \& Mathews, H.H. (1977). Benefit-Cost Study of Pinellas County Artificial Reefs. FLSGP-T-77-005, Florida Sea Grant College Program, University of Florida, Gainesville, FL. 44 p. produced for future studies in Turkey. The results of the present study have vital importance during decision-making processes for future AR deployments.

\section{Acknowledgements}

The authors thank to the head of Altınoluk Fishery Cooperative, Halil Ataç, who provided logistical support for the field work and Caner Acar, Fikret Öndes, Huriye Göncüoğlu and Denizcan Durgun for technical assistance during the face to face interviews with respondents. The authors would also like to thank the collaboration of the entities involved in answering the questionnaire. This paper was written by making use of a master dissertation called "Assessing The Socio-Economic Effects of Artificial Reef Deployments in The Northern Aegean Sea: Altınoluk Case".

Hiett, R. \& Milon, J.W. (2002). Economic Impact of Recreational fishing and Diving Associated with Offshore Oil and Gas Structures in the Gulf of Mexico. DOI Minerals Management Service Document MMS Study, $10 \mathrm{p}$.

Jensen, A. (2002). Artificial reefs of Europe: perspective and future. ICES Journal of Marine Science, 59 (suppl), S3-S13. doi: 10.1006/jmsc.2002.1298

Johns, G., Leeworthy, V.R., Bell, F.W. \& Bonn, M.A. (2001). Socioeconomic Study of Reefs in Southeast Florida, Report prepared for Miami-Dade County, Florida. Hazen and Sawyer P.C., Miami, FL, 348 pp.

Johns, G., Leeworthy, V., Bell, F., \& Bonn, M. (2003). Socioeconomic Study of Reefs in Southeast Florida. NOAA Paper.

Johns, G. (2004). Socioeconomic Study of Reefs in Martin County, Florida, Report prepared for Martin County, Florida. Hazen and Sawyer P.C., Hollywood, FL. 120 pp.

Lök, A. (1995). Evaluation of fish fauna associated with experimental artificial reefs in Hekim Island in Izmir Bay (Aegean Sea, Turkey). Ege University, Institute of Natural and Applied Sciences, Master of Science Thesis.

Lök, A. \& Tokaç, A. (2000). Turkey: A new region for artificial habitats. Jensen, A.C., Collins, K.J., and Lockwood, A.P.M. (Eds.) Artificial Reefs in European Seas. Kluwer Academic Publications, Dordrecht, The Netherlands, 21-30. doi: 10.1007/978-94-011-4215-1_2

Lök, A., Metin, C., Ulaş, A., Düzbastılar, O.F. \& Tokaç, A (2002). Artificial Reefs in Turkey. ICES Journal of Marine Science, 59: 192-195. doi: 10.1006/jmsc.2002.1221

Lök \& Gül (2005). Evaluation of fish fauna associated with experimental artificial reefs in Hekim Island in Izmir Bay (Aegean Sea, Turkey). Ege University Journal of Fisheries and Aquatic Sciences, 22: 109-114. ISSN 1300 - 1590

MAGRAMA (Ministerio de Agricultura, Alimentación y Medio Ambiente) (2008). Guía Metodológica para la Instalación de Arrecifes Artificiales. 318 p.

McGinnis, M. Fernandez, L. \& C. Pomeroy (2001). The Politics, Economics, and Ecology of Decommissioning Offshore Oil and Gas Structures. Minerals Management Service Document, MMS Publication 2001-006.

Milon, J.W. (1988a). The Economic Benefits of Artificial Reefs: An Analysis of the Dade County, Florida Reef System. Sea Grant Extension Program, University of Florida. SGR-90, Florida Sea Grant College Program, University of Florida, Gainesville, FL. 89 pp.

Milon, J.W. (1988b). A Nested Demand Shares Model of Artificial Marine Habitat Choice by Sport Anglers. Marine Resource Economics, 5: 191213.

Milon, J.W. (1989). Artificial Marine Habitat Characteristics and Participation Behavior by Sport Anglers and Divers. Bulletin of Marine Science, 44: 853862. 
Milon J.W., Holland, S.M. \& Whitmarsh, D.J. (2000). Artificial Reef Evaluation with Application to Natural Marine Habitats, CRC Press, ISBN 0-84939061-3, Florida, United States, 246 pp.

Miran B. (2003). Basic Statistics. Ege University Press, ISBN 975-9308800, Izmir, Turkey, $297 \mathrm{pp}$.

Oh, C, Ditton, R.B. \& Stoll, J.R. (2008). The Economic Value of Scuba-Diving Use of Natural and Artificial Reef Habitats. Society \& Natural Resources, 21: 455-468. doi: 10.1080/08941920701681953

Parkkila, K., Arlinghaus, R., Artell, J., Gentner, B., Haider, W., Aas, Ø., Barton, D., Roth, E., \& Sipponen, M. (2010). Methodologies for assessing socioeconomic benefits of European inland recreational fisheries. EIFAC Occasional Paper No. 46, Ankara, FAO, 112 pp.

Pendleton, L.H. (2004). Creating Underwater Value: The Economic Value of Artificial Reefs for Recreational Diving, California Artificial Reef Enhancement Program. Prepared for: The San Diego Oceans Foundation. $11 \mathrm{pp}$.

Ramos, J., Santos, M.N., Whitmarsh, D. \& Monteiro, C.C. (2007). Stakeholder perceptions regarding the environmental and socio-economic impacts of the Algarve artificial reefs. Hydrobiologia, 580: 181-191. doi: 10.1007/10750-006-0454-z

Roberts, J.K., Thompson, M.E., \& Pawlyk, P.W. (1985). Contingent Valuation of Recreational Diving at Petroleum Rigs, Gulf of Mexico. Transactions of the American Fisheries Society, 114: 214-219. doi: 10.1577/1548-8659

Seaman Jr, W. \& Sprague, L.M. (1991). Artificial habitats for marine and freshwater fisheries, Academic Press, 285 p. ISBN: 978-0-12-634345-8
Sempere, J.T.B., Esplá, A.A.R. \& Palazón J.A. (2001). Análisis del efecto producción-atracción sobre la ictiofauna litoral de un arrecife artificial alveolar en la reserva marina de Tabarca (Alicante). Bol. Inst. Esp. Oceanogr. 17 (1 y 2): 73-85. ISSN: 0074-0195

Sutton, S.G. \& Bushnell, S.L. (2007). Socio economic aspects of artificial reefs Considerations for the Great Barrier. Ocean \& Coastal Management, 50 : 829-846.

Tiryakioğlu, F.Ö. (2008). Socio-Economic Evaluation of Artificial Reefs In Aegean Sea, Turkey. University of Portsmouth Business School, Master of Science Dissertation, Portsmouth, UK, 41 pp.

Ulaş, A., Düzbastılar, F.O., Lök, A. \& Metin, C. (2007). A pre-study for determining of efficiency of fish sampling methods on artificial reefs. Ege Journal of Fisheries and Aquatic Sciences 24(3-4): 287-293.

Wedgwood, A. \& Sansom, K. (2003). Willingness-to-pay surveys - a streamlined approach: Guidance notes for small town water services. WEDC, Loughborough University, UK, ISBN 184380014 4, 234 pp.

Whitmarsh, D, Santos, M.N., Ramos, J. \& Monteiro, C.C. (2008). Marine habitat modification through artificial reefs off the Algarve (southern Portugal): An economic analysis of the fisheries and the prospects for management. Ocean \& Coastal Management, 51: 463-468.

doi:10.1016/j.ocecoaman.2008.04.004

Wilhelmsson, D., Ohman, MC, Stahl H. \& Shlesinger, Y. (1988). Artificial Reefs and Dive Tourism in Eilat, Israel. AMBIO, 27(8): 764-766. 